\title{
Chromosome Conformation Capture (3C) in Budding Yeast
}

\author{
Jon-Matthew Belton and Job Dekker ${ }^{1}$ \\ Program in Systems Biology, University of Massachusetts Medical School, Worcester, Massachusetts 01605
}

Chromosome conformation capture (3C) is a method for studying chromosomal organization that takes advantage of formaldehyde cross-linking to measure the spatial association of two pieces of chromatin. The 3C method begins with whole-cell formaldehyde fixation of chromatin. After cell lysis, solubilized chromatin is digested with a type II restriction endonuclease, and cross-linked DNA fragments are ligated together. Cross-links are reversed by degradation with proteinase $\mathrm{K}$, and chimeric DNA molecules are purified by standard phenol:chloroform extraction. The resulting 3C library represents chromatin fragments that may be separated by large genomic distances or located on different chromosomes, but are close enough in three-dimensional space for cross-linking. Locus-specific oligonucleotide primers are used to detect interactions of interest in the 3C library using end-point polymerase chain reaction (PCR).

It is essential that you consult the appropriate Material Safety Data Sheets and your institution's Environmental Health and Safety Office for proper handling of equipment and hazardous materials used in this protocol.

RECIPES: Please see the end of this protocol for recipes indicated by $<R>$. Additional recipes can be found online at http://cshprotocols.cshlp.org/site/recipes.

Agarose

$\operatorname{ATP}(100 \mathrm{~mm})$

Bovine serum albumin (BSA) $(10 \mathrm{mg} / \mathrm{mL})$

DNA ladder (1 kb) (New England Biolabs N3232S)

DNA quantification reagents for the method of choice (e.g., Bioanalyzer, qPCR, or fluorometry)

Ethanol (100\%)

Formaldehyde (37\%) (Fisher Scientific BP531-500)

Glycine $(2.5 \mathrm{M}$, filter-sterilized)

Ligation buffer for $3 \mathrm{C}(10 \times)<\mathrm{R}>$

PCR reagents, including locus-specific oligonucleotide primers for end-point PCR

3C PCR primers should be designed 100-200 bp upstream of the restriction cut site on the fragments of interest (Fig. 1B). All 3C primers should hybridize to the "-" strand. This ensures that amplification occurs only when the fragments have been digested and then ligated in the opposite (head-to-head) orientation, and eliminates falsepositive signals that can result from partial digestion products. Further discussion on 3C primer design and experimental setup can be found in Dekker (2006) and Naumova et al. (2012).

Phase Lock Gel Light tubes (15-mL) (5-Prime 2302840)

\footnotetext{
${ }^{1}$ Correspondence: job.dekker@umassmed.edu

(C) 2015 Cold Spring Harbor Laboratory Press

Cite this protocol as Cold Spring Harb Protoc; doi:10.1101/pdb.prot085175
} 


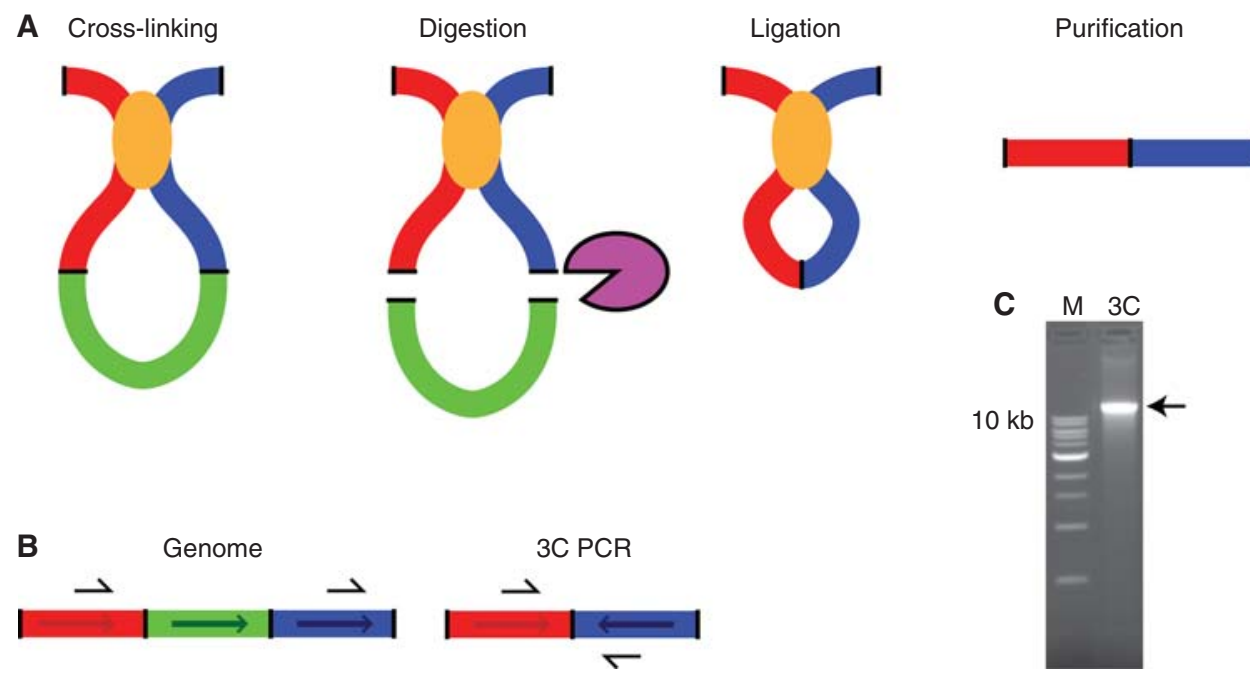

FIGURE 1. Schematic overview of the 3C procedure, primer design, and quality control. (A) A 3C library is generated by cross-linking chromatin with formaldehyde, digesting the chromatin with a restriction enzyme of choice, ligating cross-linked chromatin fragments together, and purifying the chimeric ligation products (which represent spatial interactions between pairs of restriction fragments). (B) Locus-specific 3C primers are designed 100-200 bp upstream of genomic restriction fragments. Each primer is designed to hybridize to the " - " strand so that PCR amplicons will only be formed when the two fragments of interest have been digested. This ensures that only digested ligation products are detected. (C) The $3 \mathrm{C}$ library runs at $\sim 12 \mathrm{~kb}$ on a $0.8 \%$ agarose gel, indicated by the arrow. M, 1-kb DNA ladder.

Phase Lock Gel Light tubes (50-mL) (5-Prime 2302860)

Phenol:chloroform $(1: 1)<\mathrm{R}>$

Proteinase K (Life Technologies 25530-015)

Prepare a solution of $10 \mathrm{mg} / \mathrm{mL}$ in TE buffer. $<R>$

Restriction enzyme, type II $(20,000 \mathrm{U} / \mathrm{mL})$, with the appropriate reaction buffer

Enzymes that rely on NEBuffer 4 should be avoided, as it contains acetate ions that precipitate SDS.

RNase A, DNase-free $(10 \mathrm{mg} / \mathrm{mL})$

Saccharomyces cerevisiae

Grow yeast cells (using growth medium and conditions appropriate for the strain and experiment) for 2-3 doubling times to obtain mid-log phase cells. Usually, a 200-mL culture produces enough cells to generate two or three 3C libraries.

Sodium acetate $(3 \mathrm{M}, \mathrm{pH} 5.2)<\mathrm{R}>$

Sodium dodecyl sulfate (SDS) $(10 \%$ and $1 \%[\mathrm{w} / \mathrm{v}])$

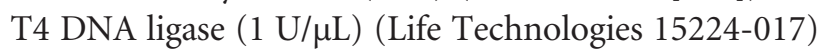

TE buffer $(1 \times)<\mathrm{R}>$

Triton X-100 (10\% [v/v])

Equipment

Centrifugal filters (Amicon 15-mL, $30 \mathrm{kDa}$ ) (Millipore UFC903024)

Centrifuge (high-speed, refrigerated, for up to $18,000 \mathrm{~g}$ )

Centrifuge (tabletop, refrigerated, for up to $3100 g$ )

DNA quantification equipment for the method of choice (e.g., Bioanalyzer, qPCR, fluorometry)

Dry ice

Flask (200-mL)

Gel electrophoresis apparatus

Incubator/shaker at $25^{\circ} \mathrm{C}$

Liquid nitrogen

Microcentrifuge tubes (1.7-mL) 
J.-M. Belton and J. Dekker

Mortar and pestle

Immediately before use, precool a mortar and pestle by placing them on dry ice and adding enough liquid nitrogen to the mortar to cover the head of the pestle. Let the liquid nitrogen evaporate before use (Step 9).

PCR plate (96-well)

Spectrometer to measure optical density at $600 \mathrm{~nm}$

Thermal cycler

Thermomixer or water baths at $16^{\circ} \mathrm{C}, 37^{\circ} \mathrm{C}$, and $65^{\circ} \mathrm{C}$

Tubes, conical (15-, 50-, and 200-mL)

Tubes, screw cap (35- and 250-mL, suitable for high-speed centrifugation)

Vacuum aspirator

Vortex

\section{METHOD}

An overview of the 3 C protocol is provided in Figure 1.

\section{Cross-Linking Chromatin}

Because the output of the 3C method is the rate of cross-linking, it is essential to standardize cross-linking across all samples. Fixation of whole cells followed by nitrogen grinding, described here, is preferable to fixation of spheroplasts, because the spheroplasting process may affect cell integrity and nuclear organization.

1. Add $37 \%$ formaldehyde to the cultured yeast cells to a final concentration of $3 \%$ of the culture medium.

2. Shake the culture at $200 \mathrm{rpm}$ for $20 \mathrm{~min}$ at $25^{\circ} \mathrm{C}$.

3. Quench the cross-linking by adding $2.5 \mathrm{~m}$ glycine at $2 \times$ the volume of formaldehyde used in Step 1 .

4. Shake the culture at $200 \mathrm{rpm}$ for $5 \mathrm{~min}$ at $25^{\circ} \mathrm{C}$.

5. Transfer the cells to a $200-\mathrm{mL}$ tube and centrifuge the cells at $1800 \mathrm{~g}$ for $5 \mathrm{~min}$ in a tabletop centrifuge.

6. Pour off the medium and wash the cells in $100 \mathrm{~mL}$ of sterile $\mathrm{H}_{2} \mathrm{O}$ by pipetting up and down until the cell pellet is resuspended.

7. Centrifuge the cells at $1800 \mathrm{~g}$ for $5 \mathrm{~min}$ in a tabletop centrifuge.

8. Pour off the supernatant and resuspend the cells in $5 \mathrm{~mL}$ of $1 \times$ restriction enzyme buffer by pipetting up and down.

9. Add liquid nitrogen to a prechilled mortar and pour the sample into the liquid nitrogen. Once the sample has frozen, begin to crush it with the pestle. When the sample is broken into little pieces, begin to grind it with the pestle. Grind the sample for $10 \mathrm{~min}$, adding liquid nitrogen as necessary (approximately every $3 \mathrm{~min}$ ).

10. Scrape the sample into a $50-\mathrm{mL}$ tube on ice. Add $45 \mathrm{~mL}$ of ice-cold $1 \times$ restriction enzyme buffer to the lysate.

11. Centrifuge the lysate at $1800 \mathrm{~g}$ for $5 \mathrm{~min}$ at $4^{\circ} \mathrm{C}$ in a tabletop centrifuge.

12. Pour off the supernatant and resuspend the cells in $1 \times$ restriction enzyme buffer to an $\mathrm{OD}_{600}$ of 10.0 .

The lysate can be stored in 5-mL aliquots at $-80^{\circ} \mathrm{C}$ for several years.

\section{Digesting Cross-Linked Chromatin}

It is critical to place the samples on ice after the incubations in Steps 18 and 23, as high temperature reverses formaldehyde cross-links.

13. If frozen, thaw one $5-\mathrm{mL}$ aliquot of lysate on ice. Transfer the lysate to a $50-\mathrm{mL}$ tube and wash with $45 \mathrm{~mL}$ of ice-cold $1 \times$ restriction enzyme buffer by inverting the tube several times. 
14. Centrifuge the lysate at $3100 \mathrm{~g}$ for $10 \mathrm{~min}$ at $4^{\circ} \mathrm{C}$ in a tabletop centrifuge.

15. Aspirate the supernatant with a vacuum. Resuspend the pellet in $3.8 \mathrm{~mL}$ of $1 \times$ restriction enzyme buffer.

16. Distribute $38 \mu \mathrm{L}$ of cells into 96 wells across one 96-well PCR plate.

17. Solubilize the chromatin by adding $3.8 \mu \mathrm{L}$ of $1 \%$ SDS per well. Mix by pipetting up and down but avoid making bubbles.

18. Incubate the plate in a thermal cycler for $10 \mathrm{~min}$ at $65^{\circ} \mathrm{C}$. Place the plate on ice immediately after the incubation.

19. Quench the SDS by adding $4.4 \mu \mathrm{L}$ of $10 \%$ Triton X-100 per well. Mix by pipetting up and down but avoid making bubbles.

20. Digest the chromatin by adding $5 \mu \mathrm{L}$ of restriction enzyme $(20,000 \mathrm{U} / \mathrm{mL})$ per well. Mix by pipetting up and down but avoid making bubbles.

21. Incubate the plate in a thermal cycler overnight at $37^{\circ} \mathrm{C}$.

22. Denature the restriction enzyme by adding $8.6 \mu \mathrm{L}$ of $10 \%$ SDS per well. Mix by pipetting up and down but avoid making bubbles.

23. Incubate the plate in a thermal cycler for $20 \mathrm{~min}$ at $65^{\circ} \mathrm{C}$. Place the plate on ice immediately after the incubation.

\section{Ligating Cross-Linked Chromatin Fragments}

Below, chromatin fragments are ligated in dilute conditions to minimize intermolecular ligation. Because variations in ligation conditions can contribute to variation in background ligation (intermolecular ligation) and reduce the signalto-noise ratio, it is essential to standardize intramolecular ligation across all samples.

24. Assemble the ligation reaction by adding the following to a 200-mL flask on ice, pooling together the 96 digestion reactions from Step 23. Mix the reaction by gently swirling but avoid making bubbles.

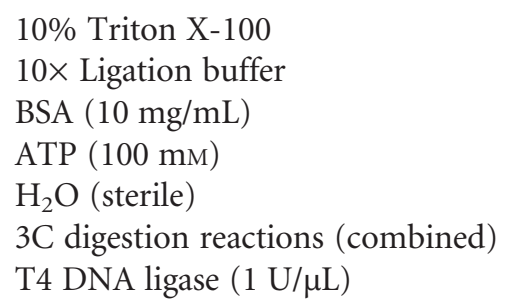

$7.15 \mathrm{~mL}$

$7.15 \mathrm{~mL}$

$768 \mu \mathrm{L}$

$768 \mu \mathrm{L}$

$57.2 \mathrm{~mL}$

$5.74 \mathrm{~mL}$

$384 \mu \mathrm{L}$

25. Split the ligation reaction into eight $15-\mathrm{mL}$ tubes $(\sim 9.6 \mathrm{~mL}$ per tube) on ice. Incubate all ligation reactions for $4 \mathrm{~h}$ at $16^{\circ} \mathrm{C}$.

\section{Reverse Cross-Links and Purifying Ligation Products}

26. Add $60 \mu \mathrm{L}$ of proteinase $\mathrm{K}(10 \mathrm{mg} / \mathrm{mL})$ to each ligation reaction from Step 25 . Mix by inverting. Incubate reactions for $4 \mathrm{~h}$ at $65^{\circ} \mathrm{C}$.

27. Add another $60 \mu \mathrm{L}$ of proteinase $\mathrm{K}(10 \mathrm{mg} / \mathrm{mL})$ to each reaction. Mix by inverting. Incubate reactions overnight at $65^{\circ} \mathrm{C}$.

28. Transfer each reaction to a $50-\mathrm{mL}$ tube. Add $19.8 \mathrm{~mL}$ of phenol:chloroform (1:1) to each tube and vortex each tube for $30 \mathrm{sec}$.

29. Pour each vortexed sample into a prespun 50-mL tube of Phase Lock Gel Light. Centrifuge at $1500 \mathrm{~g}$ for $10 \mathrm{~min}$.

30. Pour the aqueous phase of each sample into a fresh $50-\mathrm{mL}$ tube. Add $19.8 \mathrm{~mL}$ of phenol: chloroform (1:1) to each tube and vortex each tube for $30 \mathrm{sec}$. 
31. Pour each vortexed sample into a prespun 50-mL tube of Phase Lock Gel Light. Centrifuge at $1500 \mathrm{~g}$ for $10 \mathrm{~min}$.

32. Pool the aqueous phases from all samples into two 250 - $\mathrm{mL}$ tubes $(\sim 39.6 \mathrm{~mL} /$ tube).

33. Precipitate the $3 \mathrm{C}$ ligation products by adding $1 / 10$ th volumes $(3.96 \mathrm{~mL})$ of $3 \mathrm{~m}$ sodium acetate ( $\mathrm{pH}$ 5.2) and $2.5 \times$ volumes $(99.0 \mathrm{~mL}$ ) of $100 \%$ ethanol to each tube.

34. Incubate the tubes on dry ice for 30-45 min. Make sure the liquid is very cold and thick but not frozen.

35. Centrifuge the tubes at $10,000 \mathrm{~g}$ for $20 \mathrm{~min}$ at $4^{\circ} \mathrm{C}$.

36. Carefully pour off the supernatant and discard. Centrifuge at $10,000 \mathrm{~g}$ for $30 \mathrm{sec}$ at $4^{\circ} \mathrm{C}$ to collect the remaining drops of liquid at the bottom of the tube.

37. Aspirate the remaining alcohol using a vacuum.

38. Resuspend both 3C DNA pellets in $8 \mathrm{~mL}$ total of $1 \times$ TE and transfer the sample to a $50-\mathrm{mL}$ tube.

39. Add 2 volumes $(16 \mathrm{~mL})$ of phenol:chloroform (1:1) to the sample and vortex for $30 \mathrm{sec}$.

40. Transfer the sample to a prespun 50-mL tube of Phase Lock Gel Light. Centrifuge in a tabletop centrifuge at $1500 \mathrm{~g}$ for $10 \mathrm{~min}$.

41. Pour the aqueous phase into a fresh $50-\mathrm{mL}$ tube. Add 2 volumes $(16 \mathrm{~mL})$ of phenol:chloroform $(1: 1)$ and vortex the tube for $30 \mathrm{sec}$.

42. Transfer the sample to a prespun 50-mL tube of Phase Lock Gel Light. Centrifuge in a tabletop centrifuge at $1500 \mathrm{~g}$ for $10 \mathrm{~min}$.

43. Transfer the aqueous phase to a $35-\mathrm{mL}$ tube. Precipitate the $3 \mathrm{C}$ DNA with $1 / 10$ th volume (800 $\mu \mathrm{L})$ of sodium acetate (pH 5.2) and $2.5 \times$ volumes $(20 \mathrm{~mL})$ of $100 \%$ ethanol.

44. Incubate the tube on dry ice until the precipitation mixture is thick but not frozen.

45. Centrifuge the tube at $18,000 \mathrm{~g}$ for $20 \mathrm{~min}$ at $4^{\circ} \mathrm{C}$.

46. Decant the supernatant and let the 3C DNA pellet air-dry at room temperature.

47. Resuspend the sample in $15 \mathrm{~mL}$ of $1 \times \mathrm{TE}$.

48. Desalt the sample by adding it to a $15-\mathrm{mL}$ Amicon $30 \mathrm{kDa}$ filter column.

49. Centrifuge the sample in a tabletop centrifuge at $3100 \mathrm{~g}$ for $15 \mathrm{~min}$.

50. Discard the flowthrough and wash the sample once with $15 \mathrm{~mL}$ of $1 \times \mathrm{TE}$.

51. Centrifuge the sample in a tabletop centrifuge at $3100 \mathrm{~g}$ for $15 \mathrm{~min}$.

52. Pipet the 3C DNA sample out of the filter with a $200-\mu \mathrm{L}$ micropipette and transfer it to a clean 1.7-mL tube.

53. Degrade any co-precipitated RNA by adding $1 / 10$ th volume of RNase A (10 mg/mL). Incubate for $1 \mathrm{~h}$ at $37^{\circ} \mathrm{C}$.

54. Quantify the DNA using the method of choice and electrophorese the sample on a $0.8 \%$ agarose gel alongside the 1-kb DNA ladder to verify the 3C products (Fig. 1C).

The $3 \mathrm{C}$ products should appear as a tight band $\sim 12 \mathrm{~kb}$ on the gel. Any lower molecular mass smearing indicates a poor quality library and is probably caused by overvigorous lysis.

In addition to 3C-PCR (below), the resulting library alternatively can be used for 5C; see Protocol: Chromosome Conformation Capture Carbon Copy (5C) in Budding Yeast (Belton and Dekker 2015a).

\section{Performing End-Point 3C-PCR}

55. Titrate all libraries to be used in a given experiment to determine the amount needed to obtain quantitative PCR signals as follows.

i. Begin with $10 \mathrm{ng}$ of the $3 \mathrm{C}$ library. Prepare 8-10 twofold serial dilutions. 
ii. Perform PCR with each dilution using several sets of primers to detect interactions from a variety of genomic distances. For instance, use one primer pair to detect a long-range interaction (100-150 kb), another to detect a medium-range interaction (50-70 kb), and third to detect a close-range interaction (10-20 kb).

iii. Quantify the resulting products via gel electrophoresis and plot the quantities graphically.

iv. Choose a DNA amount which is in the linear range of detection for all three distances in all 3C libraries of interest, and use this amount for PCR with all primer pairs in the $3 \mathrm{C}$ experiment.

56. Conduct end-point PCR using locus-specific oligonucleotide primers to detect specific interactions of interest.

\section{RELATED INFORMATION}

When conducting 3C-PCR, it is essential to account for intrinsic biases in restriction fragments and primers. This can be accomplished by generating a random control library; see Protocol: Randomized Ligation Control for Chromosome Conformation Capture (Belton and Dekker 2015b).

\section{RECIPES}

Ligation Buffer for 3C (10x)

Reagent Amount to add (for $1 \mathrm{~L}$ ) Final concentration $(10 \times)$

Tris- $\mathrm{HCl}(1 \mathrm{M}, \mathrm{pH} 7.5)$

$500 \mathrm{~mL}$

$500 \mathrm{~mm}$

$\mathrm{MgCl}_{2}(1 \mathrm{M})$

$100 \mathrm{~mL}$

$100 \mathrm{~mm}$

Dithiothreitol (DTT) (1 M)

$100 \mathrm{~mL}$

$100 \mathrm{~mm}$

Prepare in deionized $\mathrm{H}_{2} \mathrm{O}$. Store at $-20^{\circ} \mathrm{C}$ in $15-\mathrm{mL}$ aliquots.

\section{Phenol:Chloroform (1:1)}

In a chemical fume hood, adjust the $\mathrm{pH}$ of the phenol to 8.0 with Tris buffer. Shake vigorously. Mix $500 \mathrm{~mL}$ of phenol $(\mathrm{pH} 8.0)$ and $500 \mathrm{~mL}$ of chloroform in a 1-L glass bottle with a lid. Shake the mixture vigorously and let it separate overnight at $4^{\circ} \mathrm{C}$. Store at $4^{\circ} \mathrm{C}$ for up to $1 \mathrm{mo}$.

\section{Sodium Acetate ( $3 \mathrm{M}, \mathrm{pH}$ 5.2)}

Dissolve $246.1 \mathrm{~g}$ of sodium acetate in $500 \mathrm{~mL}$ of deionized $\mathrm{H}_{2} \mathrm{O}$. Adjust the $\mathrm{pH}$ to 5.2 with glacial acetic acid. Allow the solution to cool overnight. Adjust the $\mathrm{pH}$ once more to 5.2 with glacial acetic acid. Adjust the final volume to $1 \mathrm{~L}$ with deionized $\mathrm{H}_{2} \mathrm{O}$ and filter-sterilize.

\section{TE Buffer}

\begin{tabular}{lrr} 
Reagent & Quantity (for $100 \mathrm{~mL})$ & Final concentration \\
\hline EDTA $(0.5 \mathrm{M}, \mathrm{pH} 8.0)$ & $0.2 \mathrm{~mL}$ & $1 \mathrm{mM}$ \\
Tris-Cl (1 M, pH 8.0) & $1 \mathrm{~mL}$ & $10 \mathrm{mM}$ \\
$\mathrm{H}_{2} \mathrm{O}$ & to $100 \mathrm{~mL}$ &
\end{tabular}


J.-M. Belton and J. Dekker

\section{REFERENCES}

Belton J-M, Dekker J. 2015a. Chromosome conformation capture carbon copy (5C) in budding yeast. Cold Spring Harb Protoc doi: 10.1101/pdb .prot085191.

Belton J-M, Dekker J. 2015b. Randomized ligation control for chromosome conformation capture. Cold Spring Harb Protoc doi: 10.1101/pdb .prot085183.
Dekker J. 2006. The three "C"s of chromosome conformation capture: Controls, controls, controls. Nat Methods 3: 17-21.

Naumova N, Smith EM, Zhan Y, Dekker J. 2012. Analysis of long-range chromatin interactions using Chromosome Conformation Capture. Methods 58: 192-203. 


\section{Chromosome Conformation Capture (3C) in Budding Yeast}

Jon-Matthew Belton and Job Dekker

Cold Spring Harb Protoc; doi: 10.1101/pdb.prot085175

\begin{tabular}{|c|c|}
\hline $\begin{array}{r}\text { Email Alerting } \\
\text { Service }\end{array}$ & Receive free email alerts when new articles cite this article - click here. \\
\hline $\begin{array}{r}\text { Subject } \\
\text { Categories }\end{array}$ & $\begin{array}{l}\text { Browse articles on similar topics from Cold Spring Harbor Protocols. } \\
\text { Cell Biology, general (1382 articles) } \\
\text { Genome Analysis ( } 191 \text { articles) } \\
\text { Genomic DNA (135 articles) } \\
\text { Genomic Libraries (66 articles) } \\
\text { Libraries (147 articles) } \\
\text { Molecular Biology, general (1293 articles) } \\
\text { Yeast (288 articles) }\end{array}$ \\
\hline
\end{tabular}

